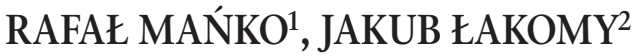

\title{
W poszukiwaniu presupozycji ontologicznych krytycznej nauki o prawie ${ }^{3}$
}

\section{Streszczenie}

Celem niniejszego artykułu jest podjęcie refleksji nad presupozycjami ontologicznymi krytycznej nauki o prawie (prawoznawstwa krytycznego), rozumianymi jako zbiór założeń z zakresu ontologii społecznej, wyznaczających tożsamość tej formy ogólnej refleksji nad prawem. Artykuł postuluje wyróżnienie czterech takich założeń: założenie o polityczności świata społecznego, założenie o społecznym tworzeniu świata społecznego, założenie o paninterpretacjonizmie, założenie o istnieniu wspólnot interpretacyjnych.

Słowa kluczowe: krytyczna nauka o prawie, ontologia społeczna, polityczność, społeczne tworzenie rzeczywistości, paninterpretacjonizm, wspólnoty interpetacyjne

1 Dr Rafał Mańko - External Fellow, Centre for the Study of European Contract Law, University of Amsterdam; e-mail: r.t.manko@uva.nl; ORCID: 0000-0003-0927-2662.

2 Mgr Jakub Łakomy - Katedra Teorii i Filozofii Prawa Wydziału Prawa, Administracji i Ekonomii Uniwersytetu Wrocławskiego; e-mail: jakub.lakomy@uwr.edu.pl; ORCID: 0000-0002-6655-6787.

3 Niniejszy artykuł został przygotowany w ramach projektu badawczego Narodowego Centrum Nauki nr 2016/21/D/HS5/03912. 


\title{
RAFAŁ MAŃKO, JAKUB ŁAKOMY
}

\section{In search for the ontological presuppositions of critical jurisprudence}

\begin{abstract}
The aim of the present article is to reflect upon the ontological presupposition of critical legal studies (critical jurisprudence), understood as a set of assumptions in the domain of social ontology which determine the identity of this form of general reflection upon law. The article proposes to identify four such assumptions: the assumption concerning the political character of the social world, the assumption on the social construction of the social world, the assumption of paninterpretationism, the assumption of the existence of epistemic communities.
\end{abstract}

Keywords: critical legal studies, social ontology, the political, social construction of reality, paninterpretationism, epistemic communism 


\section{Wprowadzenie}

Obok tradycyjnych nauk prawnych o ugruntowanej pozycji - poszczególnych dogmatyk, socjologii, historii, filozofii i teorii prawa, a także tzw. „pomocniczych nauk prawnych"4 - pojawiła się w ostatnich dekadach krytyczna nauka o prawie (critical legal studies), której status metodologiczny nie został, jak dotąd, dostatecznie wyjaśniony. Wydaje się bowiem, iż jest ona czymś więcej niż tylko wpływowym nurtem w ramach postmodernistycznej teorii (filozofii) prawa. Zdradza bowiem ambicje całościowego oglądu zjawisk prawnych z określonej perspektywy ontologicznej i epistemologicznej, proponując zupełnie nową (w naukach prawnych) metodologię. Pozostawiając na razie otwartym pytanie, czy krytyczna nauka o prawie powinna być uznawana za samodzielną subdyscyplinę jurysprudencji, czy też za dekonstrukcyjną alternatywę ogółu dotychczasowych nauk prawnych ${ }^{5}$, pragniemy w niniejszym artykule pochylić się nad jej presupozycjami ontologicznymi.

W niniejszym tekście posługujemy się pojęciem „presupozycji ontologicznych”, nie tracąc z pola widzenia, że sposób użycia przez nas tego pojęcia znamionuje pewne uproszczenie. Niektóre z omawianych poniżej presupozycji stanowią założenia z pogranicza ontologii, epistemologii, filozofii nauki, a także teorii polityki. Bardziej złożony status metateoretyczny tych presupozycji będzie sygnalizowany poniżej, jednak dla klarowności wywodu, uwzględniając fakt, iż założenia te dotyczą w znacznej mierze sfery bytu - zjawisk prawnych, funkcjonowania porządku społecznego i politycznego, pozostaniemy przy nazwie zaproponowanej w tytule niniejszego artykułu.

Twierdzimy, że w postulowanym m.in. przez T. Pietrzykowskiego podziale na „naukę prawa” (Rechtslehre) i „naukę o prawie" (Rechtswissenschaft), prawoznawstwo

4 Według ujęć podręcznikowych do grupy tzw. pomocniczych nauk prawnych zalicza się powszechnie choćby logikę prawniczą, kryminalistykę, kryminologię, wiktymologię, czy medycynę sądową. Są to nauki, które metodologię i (częściowo) przedmiot badań czerpią z innych nauk (nierzadko ścisłych), współpracując jednakże z prawoznawstwem.

5 Podkreślić należy, że wielu, szczególnie zachodnich, przedstawicieli krytycznej nauki prawa wzbrania się przed tworzeniem pozytywnej metodologii, pozytywnego korpusu tekstów i narzędzi, który ufundowałyby w sposób twardy (ontologicznie właśnie) nową naukę. Sądzimy, że postawę taką należy przezwyciężyć, kładąc tym samym podwaliny pod dialog pomiędzy krytyczną nauką o prawie a tradycyjnymi naukami prawnymi, nawet jeśli są one - prima facie - w nieprzezwyciężalnym konflikcie.

6 Por. R. Mańko, W stronę krytycznej filozofii orzekania. Polityczność, etyka, legitymizacja, Łódź 2018, s. 37. 
krytyczne sytuuje się po stronie tej drugiej, wraz z tradycyjnymi socjologią, historią, filozofią i teorią prawa ${ }^{7}$. Stąd stosowanie przez nas zamiennie nazw: „prawoznawstwo krytyczne", ,jurysprudencja krytyczna" i „krytyczna nauka o prawie". Krytyczna nauka o prawie ma w założeniu charakter metodologicznie synkretyczny ${ }^{8}$, przecina bowiem tradycyjne podziały subdyscyplinarne w obrębie nauk prawnych, chętnie korzystając $z$ dorobku teorii i filozofii oraz socjologii i socjologizującej historii prawa, by w zamierzeniu wpływać także na ustalenia dogmatyk prawniczych, choć niekoniecznie podzielając ich specyficzną metodologię. Co więcej, można zaryzykować twierdzenie, że krytyczna nauka o prawie jest programowo „adyscyplinarna”, „postdyscypliarna”, czy też „interdyscyplinarna”" ${ }^{\prime}$ uważając ścisłe podziały pomiędzy dyscyplinami prawniczymi za relikt przebrzmiałych ideologii naukowych, założeń poznawczych i metodologicznych. W ten sposób krytyczna nauka o prawie staje się nową jakością w obrębie jurysprudencji, o innych roszczeniach niż powyższe tradycyjne jej nurty i odmiany. Niewątpliwie krytyczna nauka o prawie odznacza się specyficzną, odmienną od klasycznej, synkretyczną metodologią, pozostającą wiecznie in statu nascendi ${ }^{10}$ i celem badań (emancypacyjnym) ${ }^{11}$. Patrząc na problem z innej perspektywy, bardziej klasycznej, możemy powiedzieć, że mamy do czynienia raczej z „antymetodologią", antyfundacjonalizmem naukowym, który podaje w wątpliwość sensowność wysiłków poszukiwania ontologicznych podstaw jakichkolwiek fenomenów będących przedmiotem badań (jak i podstaw samych programów badawczych) ${ }^{12}$. W takim ujęciu krytyczna nauka o prawie będzie dzieliła z klasycznymi naukami prawnymi jedynie

T. Pietrzykowski, Naturalizm i granice nauk prawnych. Esej z metodologii prawoznawstwa, Warszawa 2017, s. 31-44.

$8 \quad$ R. Mańko, W stronę..., s. 75.

9 Więcej na ten temat, por. np. J. Łakomy, Interdyscyplinarność i integracja zewnętrzna nauk prawnych w świetle postmodernistycznej krytyki, „Archiwum Filozofii Prawa i Filozofii Społecznej” 2011, 1, s. 29 -45.

10 Pojęciem „metodologii” posługujemy się tu oczywiście sensu largissimo, mając na myśli tezy dotyczące pożądanego sposobu (metody) prowadzenia badań, nawet jeżeli tezy te - jak w wypadku krytycznej nauki prawa - akcentują swego rodzaju „antymetodologię", opierając się na założenia antyfundacjonizmu. Szerzej o metodologii krytycznej nauki o prawie zob. np. A. Sulikowski, Idee i metody wspótczesnych krytycznych studiów nad prawem, "Przegląd Prawa Publicznego" 2015, 7-8.

11 Jak trafnie zauważają A. Sulikowski i K. Otręba, podejście krytyczne w prawoznawstwie „nakazuje łączyć opis i postulat, wyjaśnianie i walkę, badanie i emancypację" (A. Sulikowski, K. Otręba, O potrzebie studiów krytycznych nad prawem konstytucyjnym, „Państwo i Prawo” 2017, 3, s. 5). Zob. także A. Sulikowski, Prawa a ideologia. Prawa jednostki z perspektywy krytycznej myśli prawniczej i społecznej (wybrane zagadnienia), „Roczniki Nauk Społecznych” 2015, 4, s. 19. Por. P. Skuczyński, Typy myśli krytycznej w prawoznawstwie. Od krytyki poznania do walki o uznanie, [w:] T. Bekrycht et al. (red.), Integracja zewnętrzna i wewnętrzna nauk prawnych, t. 1, Łódź 2014, s. 134. Zob. także R. Mańko, W stronę..., s. 77.

12 Por. P. Feyerabend, Przeciw metodzie, Wrocław 1996. 
mgliście skonceptualizowany przedmiot badań, uznając go za zjawisko wielopłaszczyznowe. Należy przy tym zauważyć, że J. Wróblewski czy K. Opałek, pisząc swojego czasu o wielopłaszczyznowości badań nad prawem, pozostawali w obrębie tradycyjnie pojmowanych ontologii i epistemologii, wobec czego płaszczyzny te uznawali za realnie bądź przynajmniej epistemicznie oddzielne ${ }^{13}$. Tymczasem w krytycznej nauce o prawie, wskutek jej synkretyzmu metodologicznego, możemy raczej mówić, jak wspomnieliśmy powyżej, o postdyscyplinarności ${ }^{14}$, a nie harmonii wielu różnych perspektyw badawczych.

Celem niniejszego artykułu jest podjęcie rozważań nad presupozycjami ontologicznymi ${ }^{15}$ krytycznej nauki o prawie, rozumianymi jako te założenia z zakresu ontologii społecznej ${ }^{16}$, które są konieczne, by można było mówić w danym wypadku o krytycznej nauce o prawie, a zatem te, które są kluczowe dla tożsamości tej nauki ${ }^{17}$. Pomocniczym środkiem do poczynienia takich ustaleń będzie odwołanie się do pism przedstawicieli krytycznej nauki o prawie, zarówno zagranicznej, jak i polskiej, by w oparciu o odtworzenie, milczących nieraz, założeń ustalić, jakie są ich presupozycje ontologiczne w obszarze ontologii społecznej. Jesteśmy przy tym w pełni świadomi, że badacze zaliczani do nurtu krytycznej nauki prawa są pomiędzy sobą wewnętrznie zróżnicowani, wobec czego nieraz bardzo trudno o ustale-

13 W. Lang, J. Wróblewski, S. Zawadzki, Teoria państwa i prawa, Warszawa 1986, s. 32 i n. Szerzej o genezie powstania koncepcji wielopłaszczyznowości metodologicznej prawoznawstwa oraz ujęć prawa jako złożonych struktur zob. ibidem, s. 33; K. Opałek, Problemy metodologiczne nauki prawa, Warszawa 1962, s. 109 i n. Jerzy Wróblewski upatruje genezę wielopłaszczyznowości w koncepcjach prawa jako przeżycia emocjonalnego imperatywno-atrybutywnego. Prawo w tej koncepcji było odpowiednikiem idealnym tego przeżycia w postaci normy i odpowiednikiem realnym w postaci społecznego zachowania się. Jerzy Lande, jako uczeń Leona Petrażyckiego, pozostawał pod wyraźnym wpływem jego psychologicznych koncepcji prawa. Bardzo szeroko o historycznej i filozoficznej genezie koncepcji wielopłaszczyznowości jako odpowiedzi na krytykę bardzo jednostronnych ujęć prawa w pozytywizmie prawniczym na początku XX w., pisze Kazimierz Opałek w swojej późniejszej pracy, zob. K. Opałek, J. Wróblewski, Prawo. Metodologia, filozofia, teoria prawa, Warszawa 1991, s. 55 i n. Analizy problemu ontologicznej złożoności prawa dokonuje Jerzy Wróblewski, zob. ibidem, s. 87 i n.

14 Por. P. Nyström, Disciplinarity, Inter-disciplinarity and Post-disciplinarity: Changing Disciplinary Patterns in the History Discipline, [w:] La interdisciplinaridad y la transdisciplinaridad en la organización de conocimiento científico, León 2007.

15 Por. M. Smolak, Presupozycje ontologiczne tekstu prawnego, „Ruch Prawniczy, Ekonomiczny i Socjologiczny" 2011, 4, który definiuje to pojęcie jako ogół założeń dotyczących rzeczywistości społecznej. Marek Smolak odnosił to pojęcie do założeń leżących u podstaw tekstu prawnego wpływających na jego rozumienie, a dotyczących w znacznej mierze świata "pozatekstowego". W naszym ujęciu presupozycje ontologiczne są założeniami, które sprawiają, że określona „refleksja", zinstytucjonalizowana w dyscyplinę naukową, staje się możliwa. Oczywiście, niejako pośrednio, również są dla nas istotne presupozycje leżące u podstaw tekstów prawnych.

16 Por. B. Epstein, A Framework for Social Ontology , Philosophy of the Social Sciences” 2016, 2.

17 O tożsamości prawoznawstwa krytycznego zob. R. Mańko, W stronę..., s. 21-29. 
nie „najmniejszego wspólnego mianownika”, także ontologicznego, właściwego dla tego nurtu. Autor jednej z najbardziej znanych prac poświęconych postmodernistycznej teorii prawa, Gary Minda, bardzo szczegółowo pisze o filozoficznych podstawach ruchu studiów krytycznych nad prawem ${ }^{18}$. W dalszej części książki osobno omawia choćby jurysprudencję feministyczną (feminist jurisprudence) ${ }^{19}$ oraz krytyczną teorię rasową (critical race theory) ${ }^{20}$, które - z naszej perspektywy - bez wątpienia możemy zaliczyć do szeroko rozumianej krytycznej nauki o prawie. Charakteryzują się one jednak częściowo odmiennymi presupozycjami ontologicznymi, uwypuklając określone antagonizmy partykularne (płciowe, rasowe) kosztem fundamentalnego antagonizmu ekonomicznego (klasowego) ${ }^{21}$.

$\mathrm{Z}$ tych względów zamierzenie artykułu ma więc charakter mieszany, z jednej bowiem strony ma on cel rekonstrukcyjny, zmierzając do odtworzenia założeń (także milczących) przyjmowanych przez rzeczywiście istniejącą krytyczną naukęo prawie (moment socjologiczny), a z drugiej strony ma on także cel projekcyjny w postaci zaproponowania założeń, których spełnienie powinno stanowić przesłankę zaliczenia określonej wypowiedzi naukowej do nurtu krytycznej nauki o prawie, a nie do jednej z tradycyjnych odmian tejże nauki (moment teoretyczny) ${ }^{22}$. Jest przy tym oczywiste, że sama ontologia społeczna nie wyczerpuje wszystkich założeń, które trzeba przyjąć, aby mówić o możliwości uprawiania danej formy refleksji naukowej (czy też zaliczenia określonej wypowiedzi do danego gatunku czy podgatunku, in casu krytycznej nauki o prawie); sądzimy jednak, że podjęcie się rekonstrukcji tego akurat aspektu stanowi dogodny punkt wyjścia do dalszej

18 G. Minda, Postmodern Legal Movements. Law and Jurisprudence at Century's End, New York 1995, s. 106-127.

19 Ibidem, s. 128-148.

20 Ibidem, s. 167-185.

21 Por. ibidem, s. 106-185; I. Ward, An Introduction to Critical Legal Theory, London-Sydney 1998, s. 161 i n.

22 Oczywiście bardzo liczne są prace, które cechuje znaczący potencjał krytyczny, podzielające niektóre z omówionych poniżej presupozycji ontologicznych, bądź podzielające je w ograniczonym zakresie. Zaliczenie ich do krytycznej nauki prawa jest dość problematyczne Por. np. doskonałą rekonstrukcyjną pracę wrocławskich filozofów prawa, Przemysława Kaczmarka i Pawła Jabłońskiego, w której przybliżają oni socjologię prawa Leona Petrażyckiego, Floriana Znanieckiego, Jacka Szmatki i Piotra Sztompki: P. Kaczmarek, P. Jabłoński, Granice władzy prawniczej w perspektywie polskiej tradycji socjologicznej, Kraków 2017. Kaczmarek i Jabłoński we w prowadzeniu do tej monografii proponują autorską konceptualizację granic władzy prawniczej, wyróżniając cztery ich determinanty: 1) kultura polityczno-prawna; 2) tekst prawny; 3) kultura prawnicza; 4) czynniki podmiotowe. Takie ujęcie granic prawniczej władzy dyskrecjonalnej (albo, mówiąc inaczej, granic polityczności władzy prawniczej) zakłada, że autorzy dokonując syntezy najważniejszych prac polskiej socjologii prawa, w pewnym zakresie akceptują presupozycje ontologiczne ujęte w niniejszym artykule. 
dyskusji o krytycznej nauce o prawie, a nadto może mieć istotne znaczenie dla formułowania teoretycznych założeń badań aplikacyjnych (stosujących założenia krytycznej nauki o prawie do określonych działów prawa), np. krytycznych analiz doktryny i orzecznictwa, w szczególności w perspektywie ich związków z politycznością ${ }^{23}$.

Presupozycje wskazane w niniejszym artykule mają, w zamierzeniu, charakter katalogu minimalnego i koniecznego, tj. zaliczenie określonej wypowiedzi naukowej do nurtu krytycznej nauki o prawie możliwe jest wtedy i tylko wtedy, gdy autor danej wypowiedzi przyjmuje je wszystkie, explicite bądź w sposób dorozumiany. Równocześnie jednak przyjęcie (explicite bądź w sposób konkludentny) wskazanych presupozycji ontologicznych nie stanowi samo przez się przesłanki dostatecznej do zaliczenia określonej wypowiedzi naukowej do nurtu krytycznej nauki o prawie. Jest tak dlatego, iż krytyczna nauka o prawie dookreślana jest nie tylko poprzez swoje założenia w zakresie ontologii społecznej, ale także przez co najmniej dwa inne elementy, które choć wiążą się ściśle z zarysowanymi tutaj presupozycjami, nie muszą z nich wynikać w sposób konieczny. Są to, po pierwsze, założenie metodologiczne lokujące krytyczną naukę o prawie w kręgu tzw. hermeneutyki podejrzeń (hermeneutics of suspicion) ${ }^{24}$ oraz, po drugie, cel emancypacyjny fundujący założenia prakseologiczne krytycznej nauki o prawie. Stąd też możliwe jest, iż określona wypowiedź naukowa dzieli, co prawda, z krytyczną nauką prawa jej presupozycje ontologiczne, jednakże nie przyjmuje bądź to jej założeń metodologicznych, bądź też - co wydaje się dużo bardziej prawdopodobne w praktyce - nie podziela fundujących wszelką teorię (naukę) krytyczną celów emancypacyjnych albo wręcz ma cele zgoła odwrotne, jak choćby nurt tzw. konserwatywnych krytyków prawa (conservative crits), celnie opisanych przez A. Sulikowskiego ${ }^{25}$.

Nadto katalog presupozycji nie ma charakteru zamkniętego w tym sensie, że określone nurty krytycznej nauki o prawie mogą przyjmować szereg dodatkowych

23 Zob. ostatnio, przykładowo: H. Dębska, T. Warczok, The Social Construction of Femininity in the Discourse of the Polish Constitutional Court, [w:] R. Mańko et al. (red.), Law and Critique in Central Europe: Questioning the Past, Resisting the Present, Oxford 2016; R. Mańko, Symbolic Violence in Technocratic Law and Attempts at Its Overcoming: Politicisation through Humanization?, "Wrocławskie Studia Erazmiańskie" 2017, 11; W. Zomerski, Krytyczna analiza dyskursu sądowego dotyczącego prawnej sytuacji osób homoseksualnych w świetle art. 18 Konstytucji RP, „Archiwum Filozofii Prawa i Filozofii Społecznej" 2017, 2.

24 Por. B. Leiter, The Hermeneutics of Suspicion: Recovering Marx, Nietsche and Freud, The University of Texas School of Law. Public Law and Legal Theory Working Paper nr 72/2005, http://ssrn.com/ abstract=691002 (dostęp: 31.01.2018). Por. uwagę A. Sulikowskiego uznającego kluczową rolę myśli Marksa, Nietzschego i Freuda dla krytycznej nauki prawa (A. Sulikowski, Prawa a ideologia..., s. 19).

25 A. Sulikowski, Afirmatywna amnezja i konserwatywni 'crits'. Kilka uwag o kondycji krytycznej myśli prawniczej w Europie Środkowej i Wschodniej, „Archiwum Filozofii Prawa i Filozofii Społecznej” 2014, 1. 
presupozycji im właściwych. Dotyczy to zarówno presupozycji o charakterze uniwersalnym (np. dotyczących ideologii i jej roli w tworzeniu, wykładni i stosowaniu prawa) ${ }^{26}$, jak i o charakterze lokalnym (np. dotyczących identyfikacji grup społecznych podlegających dominacji i wymagających emancypacji, czy też dotyczących natury i zakresu konfliktów i interesów właściwych tak dookreślonym grupom).

\section{Założenie o polityczności świata społecznego}

Pierwszym i fundamentalnym, jak się wydaje, założeniem co do ontologii społecznej podzielanym przez wszelkie nurty krytycznej nauki prawa, od klasycznych (amerykański ruch Critical Legal Studies) po rozmaite odmiany powstałe później (krytyczna teoria rasowa, jurysprudencja feministyczna), a nawet włączając nurty pozostające na marginesie głównego nurtu krytycznej nauki prawa (jak krytyczna socjologia prawa nawiązująca do założeń metodologicznych P. Bourdieu) - jest założenie o polityczności świata społecznego ${ }^{27}$. Pojęcie „polityczności” rozumieć tu należy za C. Schmittem ${ }^{28}$, C. Mouffe i E. Laclau ${ }^{29}$ oraz autorami do nich nawiązującymi (jak S. Žižek, A. Sulikowski ${ }^{30}$ czy M. Paździora i M. Stambulski ${ }^{31}$ ) nie jako prosty związek z polityką czy zdeterminowanie przez politykę, ale jako wymiar

26 Por. D. Šulmane, Ideology, Nationalism and Law: Legal Tools For An Ideological Machinery in Latvia, „Wrocław Review of Law, Administration and Economics” 2015, 1; M. Stambulski, The Critique of Ideological Legal Reason, "Wrocław Review of Law, Administration and Economics” 2015, 1(1); W. Zomerski, Ideology In Modern Times: Three Ideological Lies Behind Universal Human Rights, „Wrocław Review of Law, Administration and Economics" 2015, 1; M. Škop, The Importance of Being a Linguist: Critical Legal Thought in Central Europe, [w:] R. Mańko et al. (red.), Law and Critique in Central Europe: Questioning the Past, Resisting the Present, Oxford 2016, s. 40-41; R. Mańko, Ideology and Legal Interpretation: Some Theoretical Considerations, [w:] K. Torgāns et al. (red.), Constitutional Values in Contemporary Legal Space, t. 1, Riga 2016; W. Zomerski, Krytyczna analiza...

27 W kwestii relacji prawa i polityczności zob. np.: C. Douzinas, R. Warringron, S. McVeigh, Postmodern Jurisprudence. The Law of Text in the Texts of Law, London-New York 1991; C. Douzinas et al. (red.), Politics, Postmodernity and Critical Legal Studies. The Legality of the Contingent, London-New York 1994; C. Douzinas, A. Gearey, Critical Jurisprudencje. The Political Philosophy of Justice, Oxford-Portland 2005; M. Stone et al. (red.), New Critical Legal Thinking. Law and the Political, Abingdon 2014. C. Schmitt, Pojęcie polityczności, [w:] idem, Teologia polityczna i inne pisma, Warszawa 2012.

C. Mouffe, E. Laclau, Hegemonia i socjalistyczna strategia. Przyczynek do projektu radykalnej polityki demokratycznej, Wrocław 2005.

30 A. Sulikowski, Trybunat Konstytucyjny a polityczność. O konsekwencjach upadku pewnego mitu, „Państwo i Prawo" 2016, 4.

31 M. Paździora, M. Stambulski, Co może dać nauce prawa polityczność? Przyczynek do przyszłych badań, „Archiwum Filozofii Prawa i Filozofii Społecznej” 2014, 1, s. 55-56; M. Stambulski, Polityczność jako etyka polityczna prawa, [w:] M. Dudek et al. (red.), Aksjologiczny wymiar prawa, Kraków 2015. 
nieusuwalnego konfliktu przeszy wający społeczeństwo ${ }^{32}$. Założenie o polityczności świata społecznego oznacza więc, że konflikt jest wpisany we wszelkie zjawiska społeczne i nie może on być w sposób ostateczny usunięty ${ }^{33}$. Społeczeństwo jest więc niejako skazane na konflikty i konieczne jest wypracowanie mechanizmów ich instytucjonalizacji, nie jest natomiast możliwa ich likwidacja (niemożliwe jest tzw. społeczeństwo harmonijne, pozbawione wszelkich konfliktów $\left.{ }^{34}\right)$. Rozwinięciem tezy o polityczności świata społecznego są określone typy (rodzaje) konfliktów. Wydaje się, że konsensusem krytycznej nauki o prawie objęte jest stwierdzenie, iż jednym z takich konfliktów jest konflikt klasowy (a zatem mający charakter ekonomiczny $)^{35}$. Rozbieżności dotyczą natomiast tego, na ile konflikt ten ma charakter zasadniczy (tu uwidaczniają się różnice pomiędzy klasycznym nurtem, nawiązującym wprost do założeń marksizmu, a nurtami późniejszymi, podkreślającymi wagę konfliktów kulturowych), a także co do tego, jakie inne konflikty są doniosłe w perspektywie krytycznej nauki o prawie, a które mają charakter nieistotny, a zatem pomijalny $w$ analizach dokonywanych przez przedstawicieli omawianego nurtu ${ }^{36}$.

Założenie o polityczności przeciwstawia prawoznawstwo krytyczne zarówno tym nurtom, które uznają, iż konflikt jest poza zakresem ich zainteresowań (dogmatyki prawnicze, klasyczny pozytywizm), jak i tym nurtom, które choć istnienie konfliktów uznają, jednakże zakładają, iż możliwe jest ich rozładowanie na drodze odpowiednio wypracowanych ram dla zinstytucjonalizowanego dialogu społecznego (nurty liberalne w filozofii prawa, np. J. Habermas) ${ }^{37}$. Założenie o konflikcie, jako podstawowym i nieodłącznym wymiarze ontologii społecznej łączy natomiast krytyczną naukę o prawie z określonymi nurtami, których do niej samej zaliczyć nie można z racji ich nieemancypacyjnego, czy wręcz antyemancypacyjnego charakteru (np. filozofia prawa C. Schmitta).

Założenie o polityczności świata społecznego pociąga za sobą konieczność przyjęcia dalszych presupozycji ontologicznych, a w szczególności założenia, iż możliwe jest wyodrębnienie określonych grup społecznych, które pozostają ze sobą w relacji konfliktu interesów. Tak jak zostało to zasygnalizowane wyżej, grupy te mogą być wyodrębniane wedle rozmaitych kryteriów, przy czym determinantą jest tu założenie o określonej naturze konfliktu. A zatem, wychodząc od założenia o ekonomicznej naturze konfliktu, identyfikować będziemy klasy społeczne (w oparciu o stosunek

\footnotetext{
32 C. Mouffe, Polityczność, Kraków 2015.

33 R. Mańko, W stronę..., s. 147-151.

34 Ibidem, s. 40.

35 Ibidem, s. 27, 79.

36 Por. A. Sulikowski, K. Otręba, op. cit., s. 7.

37 Por. R. Mańko, W stronę..., s. 56, 61, 151, 249.
} 
do własności środków produkcji - klasa właścicieli środków produkcji, zwana tradycyjnie z francuska burżuazją, czyli mieszczaństwem, oraz klasa pracownicza, zwana tradycyjnie klasą robotniczą). Możliwe jest jednak wyróżnianie innych grup społecznych w oparciu o kryteria ekonomiczne, a tezę o dwuklasowości trudno uznać za nieodzowny fundament krytycznej nauki o prawie. Przyjęcie odmiennych kryteriów wyróżniania konfliktów skutkować będzie identyfikacją odmiennych grup wyposażonych $w$ interesy i pozostających $w$ odniesieniu do tych interesów w konflikcie, jak np. mniejszości kulturowych, rasowych czy obyczajowych $^{38}$.

Przyjęcie, że konflikty mają charakter permanentny, skutkuje także założeniem, że zawsze jedna ze stron konfliktu ma przewagę nad drugą - tj. występowania w świecie społecznym zjawiska dominacji jednych grup nad innymi. Charakter dominacji jest przy tym pochodną charakteru konfliktu (dominacja ekonomiczna, dominacja kulturowa).

Założenie o polityczności pociąga za sobą poza wyróżnieniem określonych grup jako bytów społecznych także uznanie istnienia kategorii interesu, jako czegoś, o czym można predykować, iż istnieje społecznie. Interes ten dla potrzeb krytycznej nauki prawa definiowany jest szeroko, nie tylko jako interes ekonomiczny, ale także jako interes w postaci roszczenia do uznania (Heglowskiej Anerkennung) ${ }^{39}$, interes kulturowy (posługiwanie się własnym językiem) czy też szeroko rozumiany interes osobisty. Przyjęcie istnienia interesu, jako kategorii doniosłej na gruncie ontologii społecznej presuponowanej przez krytyczną naukę prawa, pozostaje w ścisłym związku z celami emancypacyjnymi tej nauki, których osiągnięcie ma się stać możliwe właśnie poprzez realizację określonych interesów, które w warunkach podlegających krytyce nie mogą być realizowane (np. interesy klasy pracowniczej, interesy mniejszości kulturowych, rasowych i obyczajowych $)^{40}$.

Podsumowując tę część rozważań, należy wskazać, że ontologia społeczna presuponowana przez krytyczną naukę prawa zakłada fundamentalny charakter wymiaru konfliktu społecznego (polityczność), co z kolei presuponuje istnienie określonych, dających się wyróżnić grup pozostających ze sobą w konflikcie oraz interesów dających się tym grupom przypisać, których pełna realizacja (w wypadku grup zdominowanych) jest tożsama z celem emancypacyjnym krytycznej nauki prawa, tj. dążeniem do wyzwolenia określonych grup spod dominacji (ekonomicznej i kulturowej).

\footnotetext{
38 P. Skuczyński, Typy myśli krytycznej..., s. 146-147.

39 Ibidem, s. 147.

40 R. Mańko, W stronę..., s. 42.
} 


\section{Założenie o społecznym tworzeniu świata społecznego}

Drugim fundamentalnym elementem ontologii społecznej presuponowanym przez krytyczną naukę prawa jest, jak się wydaje, teza o konstrukcjonizmie społecznym, tj. o społecznym wytwarzaniu świata społecznego ${ }^{41}$. Innymi słowy, dla krytycznej nauki o prawie ontologia społeczna nie jest czymś raz na zawsze danym i podlegającym jedynie biernej analizie, ale czymś, co jest tworzone społecznie i co może być przedmiotem zmiany ${ }^{42}$, także dokonywanej przez zaangażowanych badaczy ${ }^{43}$. Tezę tę lapidarnie oddaje XI teza o Feuerbachu, wedle której celem filozofii jest nie tyle interpretacja świata, co jego zmiana. Nie wdając się w problem, czy istotnie rzeczona teza sensownie oddaje zadania filozofii w ogólności, czy też należy ją odnosić jedynie do filozofii krytycznej, przyjąć należy, iż założenie o społecznym tworzeniu (produkcji i reprodukcji) stosunków społecznych stanowi presupozycję sine qua non krytycznej nauki o prawie, a to z uwagi na jej emancypacyjny charakter. Krytyczna nauka o prawie zakłada bowiem, iż prawo, jak i regulowane przez nie stosunki, są produktami społecznego wytwarzania rzeczywistości i jako takie mogą być poddawane krytyce w celu ich zmiany ${ }^{44}$. W przeciwnym wypadku krytyka prawa będąca podstawowym narzędziem dyskursywnym krytycznej nauki prawa pozbawiona byłaby sensu, a założenie o jej emancypacyjnym celu musiałoby zostać usunięte, co równocześnie pozbawiłoby krytyczną naukę prawa jej istoty. Podkreślić przy tym należy doniosłe konsekwencje delegitymizacyjne przyjmowanych przez krytyczną naukę prawa tez, które niewątpliwie zmierzają do osłabienia autorytetu tradycyjnych nauk prawnych i ich metodologii, a w szczególności - dogmatyk i właściwej im metody badawczej, nastawionej na formalno-pojęciową, a nie polityczną, analizę fenomenów prawnych.

Omawianą tezę krytyczna nauka o prawie dzieli z większością współczesnej humanistyki, a w szczególności z dominującymi dziś nurtami w socjologii, filozofii

41 Klasyczne ujęcie tej tezy w pracy: P.L. Berger, T. Luckmann, Społeczne tworzenie rzeczywistości, Warszawa 1983.

42 R. Mańko, W stronę..., s. 38.

43 Oczywiście, przyjęcie tezy o społecznym tworzeniu rzeczywistości nie implikuje automatycznie przyjęcia postawy zaangażowanej. Twórcy konstrukcjonizmu społecznego, Berger i Luckmann, choć podkreślali przygodność określonego urządzenia społeczeństwa, bynajmniej nie nawoływali do zmian emancypacyjnych, pozostając na pozycjach opisu, a nie krytycznego zaangażowania. Podobnie rzecz się ma z Arturem Kozakiem, który przyjmując tezy konstrukcjonizmu społecznego w odniesieniu do wspólnoty prawniczej nawoływał wręcz do jej umocnienia względem innych subświatów instytucjonalnych (polityki, gospodarki), zamiast do emancypacji tych ostatnich spod kurateli subświata prawniczego. Zob. A. Kozak, Granice prawniczej władzy dyskrecjonalnej, Wrocław 2002, zwł. rozdział Instytucjonalizacja jako kreowanie rzeczywistości.

44 R. Mańko, W stronę..., s. 38. 
czy kulturoznawstwie. W socjologii prawa tezę tę przyjmuje w szczególności nurt socjologii krytycznej inspirowanej myślą P. Bourdieu ${ }^{45}$.

Założenie to odróżnia natomiast krytyczną naukę o prawie w sposób zdecydowany od dogmatyk prawniczych ${ }^{46}$, dla których tekst prawny stanowi zasadniczy punkt odniesienia i nie jest on traktowany jako coś, co sama nauka mogłaby zmienić, lecz jako coś, co pragnie ona zrozumieć, zakładając zazwyczaj, iż ma ono jedno prawidłowe znaczenie (o które mogą się toczyć "spory w doktrynie") ${ }^{47}$. Dogmatyki uznają wprawdzie, że tekst prawny jest tworem ustawodawcy (a zatem produktem społecznym), jednakże, w odróżnieniu od krytycznej nauki o prawie, nauki te traktują rzeczony tekst prawa jako "dogmat”, a zatem wypierają jego konstruktywistyczny charakter, traktując społeczny konstrukt jako aksjomat, a nie plastyczny przedmiot krytyki ${ }^{48}$. Co się zaś tyczy relacji pomiędzy krytyczną nauką prawa a filozofią prawa, należy podkreślić, że część nurtów tej ostatniej również przyjmuje społeczne wytwarzanie prawa i regulowanych przez nie stosunków - jak np. stworzony przez A. Kozaka juryscentryzm ${ }^{49}$, a także nurty szeroko rozumianego pragmatyzmu prawniczego - inne natomiast stają na stanowisku możliwości odkrycia i opisania prawd i prawideł rządzących światem społecznym, które nie są wytwarzane społecznie, lecz są dane z zewnątrz, a zatem determinują świat społeczny. Ze starszych nurtów filozofii prawa przyjmujących to założenie wymienić należy jusnaturalizm, a z nowszych - nurty inspirowane naukami ścisłymi, a w szczególności kognitywistyką i ekonomią klasyczną (ekonomiczna analiza prawa). Nie znaczy to oczywiście, że jusnaturaliści czy zwolennicy naturalizacji prawoznawstwa na modłę kognitywistyczną bądź ekonomiczną nie formułują krytycznych uwag pod adresem prawa obowiązującego, jednakże odmienna aniżeli w wypadku krytycznej nauki prawa jest podstawa tych uwag

45 Por. zwięzłą prezentację podstawowych założeń socjologii krytycznej P. Bourdieu (w odniesieniu do prawa) w pracach: H. Dębska, Władza, symbol, prawo. Spoteczne tworzenie Trybunału Konstytucyjnego, Warszawa 2015, s. 15-71; eadem, Prawo jako pole (ujęcie modelowe), „Państwo i Prawo" 2016, 9.

46 R. Mańko, W stronę..., s. 39.

47 Mamy tu na myśli milczące supozycje większości przedstawicieli naukowego dyskursu dogmatycznego. Odmiennie rzecz się ma w filozoficznoprawnych modelach dogmatyki formułowanych na gruncie tzw. miękkiego pozytywizmu, gdzie programowo dopuszcza się współtworzenie treści prawa przez jego naukę, a więc eo ipso także jego zmianę. Por. np. M. ZirkSadowski, Prawo a uczestniczenie w kulturze, Łódź 1998; J. Leszczyński, Pozytywizacja prawa w dyskursie dogmatycznym, Kraków 2010. Nadto należy oczywiście zaznaczyć, że hermeneutyki niepodejrzliwe również akceptują, że przedmiot poznania jest współtworzony przez podmiot poznania, jednakże - w odróżnieniu od krytycznej nauki prawa - z konstatacji tej nie wynikają cele krytyczne i emancypacyjne.

48 R. Mańko, W stronę..., s. 39-40.

49 A. Kozak, Granice prawniczej...; idem, Myślenie analityczne w nauce prawa i praktyce prawniczej, Wrocław 2012. 
- wynikają one albo z założeń konfesyjno-etycznych (jak w wypadku jusnaturalizmu klasycznego), albo też z założeń scjentystycznych (jak w wypadku nowych nurtów naturalizacyjnych w prawoznawstwie - które można określić, odpowiednio, jako biologizm czy ekonomizm prawniczy). Krytyczna nauka o prawie ostro odróżnia się od obu tych podejść, stojąc zdecydowanie na stanowisku, że jej celem jest nie tylko opisanie i interpretacja społecznych uwarunkowań zjawisk prawnych, ale także ich fundamentalna krytyka jako przygodnych wytworów społecznych i wpływanie na ich zmianę w pożądanym (tj. emancypacyjnym) kierunku.

\section{Założenie o paninterpretacjonizmie}

Trzecim istotnym elementem ontologii społecznej presuponowanym przez krytyczną naukę o prawie jest założenie o paninterpretacjonizmie społecznym, polegające na tym, iż wszelkie zjawiska społeczne - w tym w szczególności teksty i inne zjawiska prawne - podlegają interpretacji i nie mogą być przez aktorów społecznych postrzegane przed czy poza interpretacją ${ }^{50}$. Paninterpretacjonizm jest stanowiskiem, wedle którego każde poznanie jest zrelatywizowane do perspektywy podmiotu poznającego. Innymi słowy wszelkie poznanie jest z natury swej interpretacją, wobec czego nie istnieje coś takiego jak poznanie niezrelatywizowane do żadnej perspektywy, czyli dostarczające, jak to metaforycznie ujmuje filozof Thomas Nagel, „Widoku znikąd" ${ }^{21}$. Jak powiada amerykański pragmatysta Richard Shusterman ${ }^{52}$, według painterpretacjonizmu „widzimy wszystko przez »zasłonę« interpretacji lub z punktu widzenia narzucającego jakąś interpretację. (...) nie tylko widzimy wszystko przez interpretację, lecz (...) wszystko jest przez nią konstytuowane. Nie ma, innymi słowy, nic rzeczywistego (a z pewnością rzeczywistego dla nas), co nie byłoby interpretowane ${ }^{\prime \prime 53}$. Źródeł takiego stanowiska R. Shusterman upatruje w perspektywizmie Nietzschego, a jego najpełniejszy wyraz - we współczesnej filozofii interpretacji amerykańskiego neopragmatysty Stanleya Fisha. Właśnie ten ostatni, w swoim słynnym eseju, w którym polemizuje z Ronaldem Dworkinem ${ }^{54}$, stwier-

$50 \quad$ R. Mańko, W stronę..., s. 67.

$51 \quad$ T. Nagel, Widok znikąd, Warszawa 1997.

52 R. Shusterman, Estetyka pragmatyczna. Żywe piękno i refleksja nad sztuką, Wrocław 1998, s. 115 i n. (rozdz. 4: Interpretacja i rozumienie). Choć w rozdziale tym Richard Shusterman krytykuje skrajności stanowiska paninterpretacjonistycznego, to jednak jego rekonstrukcja wydaje się być rzetelna, spójna i całościowa.

53 Ibidem, s. 115-116.

54 Szerzej o polemice Ronalda Dworkina ze Stanleyem Fishem zob. np. J. Łakomy, Spory wokót wykładni prawa między nowoczesnościq a ponowoczesnościq. Na przykładzie debaty Dworkina z Fishem, [w:] 
dza, iż nawet w bezrefleksyjnym, prostym, wstępnym akcie rozumienia „interpretacja wykonała już swoje dzieło" ${ }^{55}$.

Jest to założenie o tyle istotne, że determinuje ono - podobnie jak założenie o konstrukcjonizmie społecznym - status bytów przynależących do presuponowanej przez krytyczną naukę o prawie ontologii społecznej. Byty te bowiem - jak choćby wskazane powyżej konflikty, klasy, interesy - podlegają interpretacji i tylko po dokonanej interpretacji mogą być one przedmiotem badania przez krytyczną naukę prawa. Można nawet twierdzić, że samo poznanie określonych zjawisk w badaniu naukowym jest już ich interpretacją, przefiltrowaną przez kategorie poznawcze (episteme), kształtowane ze względu na umiejscowienie w strukturze konfliktów społecznych.

Co oczywiste, interpretacji podlegają też wszelkie zjawiska prawne, a w szczególności teksty (akty prawa stanowionego, precedensy). Przyjmując założenia paniterpretacjonizmu, krytyczna nauka o prawie zakłada, że wszystko jest interpretacją, co prowadzi do zlania się kategorii poznania źródeł prawa w ujęciu tradycyjnym z innymi kategoriami, takimi jak poznanie faktów czy wykładnia prawa. Co istotne, dla krytycznej nauki o prawie interpretacja jest procesem per se twórczym, innymi słowy podmiot poznania (np. sędzia) współtworzy przedmiot poznania, jakim jest znaczenie tekstu prawnego. W tym więc sensie na płaszczyźnie ontologii społecznej krytyczna nauk o prawie presuponuje istnienie znaczeń, wytwarzanych w procesie interpretacji, a także istnienie samych tekstów, które jednak bez interpretacji są wyłącznie materialnymi ciągami znaków i nie posiadają żadnego znaczenia niezależnego od procesu interpretacji. Takie zjawiska kultury prawnej jak tekstualizm (w Stanach Zjednoczonych) czy wykładnia językowa przepisu (w Polsce) są tylko postaciami interpretacji i są, co do zasady, równie uprawnionymi metodami odczytania tekstów co konkurencyjne wobec nich metody, takie jak wykładnia teleologiczna, dynamiczna i inne.

Rozwinięciem presupozycji o interpretacjonizmie społecznym mogą być założenia dotyczące realności ideologii, której byt w ramach ontologii społecznej bywa lokowany już to w świadomości społecznej (klasyczna teza o ideologii jako fałszywej świadomości ${ }^{56}$ ), już to w praktykach społecznych (teza Žižka-Sloterdijka

A. Samonek (red.), Teoria prawa między nowoczesnościq a ponowoczesnościa, Kraków 2012; idem, The Space of the Political in Legal Interpretation (Some Remarks on the Dworkin-Fish Debate), [w:] P. Bieś-Srokosz, J. Srokosz, R. Mańko (red.), Law, Space and the Political: An East/West Perspective, Częstochowa 2017.

55 S. Fish, Working on the Chain Gang: Interpretation in the Law and in Literary Criticism, "Critical Inquiry” 1982, 9, s. 204.

56 Por. H. Dębska, Law's Symbolic Power: Beyond The Marxist Conception of Ideology , "Wrocław Review of Law, Administration and Economics" 2015, 1, s. 5-6. 
o cynicznym podmiocie ideologii $)^{57}$. Niemniej jednak wydaje się, że rozwinięte presupozycje dotyczące zjawiska ideologii - jako pewnej formy bytu społecznego - nie są niezbędne dla krytycznej nauki prawa jako takiej, a zatem nie należą do jej istoty, co nie oznacza wszak, że nie mogą stanowić pomocnego narzędzia krytyki prawa w ramach określonych wariantów tejże nauki, przyjmujących kluczową rolę ideologii w tworzeniu i interpretowaniu rzeczywistości społecznej, w tym społecznie konstruowanej rzeczywistości prawnej ${ }^{58}$. Problematykę ideologii należy jednak, jak się wydaje, lokować wśród założeń metodologicznych krytycznej nauki prawa, a niekoniecznie - w ramach jej presupozycji ontologicznych ${ }^{59}$.

\section{Założenie o istnieniu wspólnot interpretacyjnych}

Założenia o społecznym konstruowaniu rzeczywistości oraz o paninterpretacjonizmie implikują założenie o istnieniu wspólnot interpretacyjnych, w obrębie których wytwarzane są w sposób intersubiektywny znaczenia ${ }^{60}$. Dla krytycznej nauki prawa wspólnota prawnicza jest, obok swoich funkcji politycznych (w zakresie regulowania konfliktów społecznych) zawsze już wspólnotą interpretacyjną, nadającą sensy tekstom prawnym (wykładnia prawa) oraz dokonującą jurydycznej klasyfikacji zjawisk społecznych w procesie stosowania prawa ${ }^{61}$. Wspólnota prawnicza pozostaje, co oczywiste, w konkurencji do innych wspólnot w danym społeczeństwie, a nadto możliwe są konflikty w obrębie samej wspólnoty (walki o hegemonię), jak i pomiędzy wspólnotami. Tym sposobem założenie o istnieniu wspólnot interpretacyjnych, będące pochodną założenia o interpretacjonalizmie, łączy się także ściśle z założeniem o polityczności - to ostatnie rozciąga się na samą wspólnotę interpretacyjną prawników.

Założenie o istnieniu wspólnot interpretacyjnych jest wspólne dla krytycznej nauki prawa oraz dla niektórych nurtów filozofii prawa. Obce jest ono natomiast dogmatykom prawniczym, które stoją na stanowisku, iż możliwe jest poznanie rze-

57 S. Žižek, The Sublime Object of Ideology, London 2008, s. 30. Por. R. Mańko, Koncepcja interpelacji ideologicznej a krytyczny dyskurs o prawie, „Archiwum Filozofii Prawa i Filozofii Społecznej” 2004, 8, s. 42.

58 Zob. szerzej: R. Mańko, W stronę..., s. 47-62.

59 Por. A. Sulikowski, K. Otręba, op. cit., s. 6: „,w teoretyzowaniu krytycznym chodzi o udowodnienie ideologiczności i polityczności ukrytej w pseudoneutralnych konstruktach teoretycznych dominujących w łonie nauk społecznych (...)". Por. także T. Pietrzykowski, op. cit., s. 127, który trafnie podkreśla demaskatorską metodologię leżącą u podstaw krytycznej nauki o prawie.

60 R. Mańko, W stronę..., s. 72.

61 Ibidem, s. 107-110. 
czywistego znaczenia norm i pojęć prawnych, które stanowią przedmiot poznania niezależny od poznających je prawników. Także analityczna teoria prawa traktuje swój przedmiot badań jako możliwy do poznania w sposób obiektywny, a nie jako wytwór określonej wspólnoty interpretacyjnej.

Zdefiniowanie pojęcia wspólnot interpretacyjnych nie jest proste. Najpełniejszy wykład tej koncepcji zaproponował w literaturze filozoficznoprawnej wspomniany już S. Fish, który w eseju zatytułowanym Jak rozpoznać wiersz, gdy się go widzi formułuje pewną tezę dotyczącą znaczeń tekstów, która jest istotna dla zrozumienia tej koncepcji, pisząc, iż „znaczenia nie są własnością ani ustalonych i trwałych tekstów, ani też niezależnych czytelników, ale wspólnot interpretacyjnych, które są odpowiedzialne zarówno za kształt działań czytelnika, jaki za teksty powstałe w ich wyniku"62.

Jest to stanowisko dość nietypowe, gdyż sytuuje się poza dychotomią ",subiektywności” i „obiektywności” interpretacji (gdzie w pierwszym wypadku poprawność interpretacji jest sprawą subiektywną, determinowaną przez jednostkowy punkt widzenia czytelnika, zaś w drugim przez jakąś niezależną od czytelnika, zewnętrzną instancję) oraz poza dychotomią "tekstualizmu" i klasycznie pojmowanego "intencjonalizmu” (gdzie zewnętrzną instancją decydującą o poprawności interpretacji jest albo intencja autora tekstu, albo litera tegoż tekstu). Jest to szczególnie istotne z naszej perspektywy, gdyż wiąże się w sposób istotny z innymi presupozycjami ontologicznymi przez nas wyróżnionymi, przede wszystkim z założeniem o polityczności świata społecznego omówionym powyżej.

Samą wspólnotę interpretacyjną S. Fish w przywołanym wyżej eseju postrzega nie jako "grupę jednostek", podzielających określony punkt widzenia, ale jako "punkt widzenia” sam w sobie, "sposób organizowania doświadczenia”, który kieruje myśleniem i działaniem określonej grupy jednostek. Siła owego punktu widzenia jest tak znaczna, że Fish, pisząc o jednostkach, które go podzielają, używa określeń „własność wspólnoty”63. Leszek Drong, jeden z najwnikliwszych badaczy teorii amerykańskiego neopragmatysty, proponuje własną definicję wspólnoty interpretacyjnej: „Trafniejsze wydaje się (...) ostrożniejsze określenie wspólnot jako narzędzia opisu [podkr. R.M. i J.Ł.] używanego w celu podkreślenia komunalnego - czyli społecznie i ideologicznie uwarunkowanego - charakteru wszelkiego poznania"64. Echo koncepcji wspólnot interpretacyjnych S. Fisha można odnaleźć w teorii juryscentryzmu A. Kozaka, który zresztą do Fisha otwarcie nawiązywał. Chociaż ani Fish, ani Kozak nie mogą być zaliczeni do przedstawicieli krytycznej

62 S. Fish, Interpretacja, retoryka, polityka, Warszawa 2008, s. 81.

63 Ibidem, s. 251.

64 L. Drong, Od konwencjonalizmu do normatywizmu. Kilka uwag o ewolucji poglądów teoretycznoliterackich Stanleya Fisha, „ER(R)GO. Teoria. Literatura. Kultura” 2016, 12, s. 27. 
nauki o prawie sensu stricto ${ }^{65}$, wydaje się jednak, że przyjęcie założeń paniterpretacjonizmu i kluczowej roli wspólnot interpretacyjnych (nie tylko zresztą prawniczych) stanowi warunek sine qua non uprawiania krytycznie zorientowanego prawoznawstwa. Paninterpretacjonizm daje podstawę do krytyki klasycznych ujęć stosowania prawa i wykładni prawa, kwestionując dystynkcje: tworzenie i stosowanie prawa, a także ocenę stanu faktycznego i interpretację przepisów prawnych. Zamazanie dychotomii: poznanie faktów - ocena (prawna, moralna, polityczna) otwiera nowe pola do krytyki zjawisk związanych z prawem. Koncepcja wspólnot interpretacyjnych (wraz z założeniami epistemologicznymi wspomnianymi powyżej) musi być przyjmowana i analizowana równolegle z założeniem polityczności prawa, stanowiąc jej uszczegółowienie i dopełnienie - łącząc ontologię społeczną, filozofię języka epistemologię (paninterpretacjonizm), socjologię (prawa), a także teorię polityki.

\section{Presupozycje dotyczące zjawisk prawnych}

Presupozycje ontologiczne krytycznej nauki prawa w odniesieniu do fenomenu prawa (jurydyczności) stanowią pochodną założeń dotyczących natury świata społecznego omówionych w punktach poprzedzających ${ }^{66}$. Dlatego też natura prawa presuponowana przez krytyczną naukę o prawie zostanie ujęta poprzez odwołanie się do wskazanych wyżej założeń z zakresu ogólnej ontologii społecznej. Po pierwsze więc wypada zauważyć, że prawo jest z perspektywy krytycznej nauki prawa polityczne, $\mathrm{w}$ tym znaczeniu, iż reguluje ono konflikty społeczne, a zarazem jego konkretna treść stanowi wyraz aktualnych (w danym miejscu i czasie) pozycji zajmowanych przez pozostające ze sobą $\mathrm{w}$ relacji polityczności grupy społeczne. Innymi słowy, konkretna treść np. prawa pracy, prawa cywilnego czy prawa konstytucyjnego nie tylko sama reguluje konflikty (co przyznaje większość nauk prawnych), ale też stanowi wyraz aktualnego stanu toczących się konfliktów (np. klasowych, etnicznych, światopoglądowych, kulturowych). Tak ujmowane prawo pozostaje więc z konfliktami przez nie regulowanymi w relacji dialektycznej. Takie założenie jest zresztą niezbędne w kontekście emancypacyjnych celów krytycznej nauki prawa, która w zamierzeniu jej przedstawicieli ma wpłynąć na tę dialektykę choćby poprzez odsłanianie konfliktów „zamrożonych”

65 Por. A. Sulikowski, Konstytucjonalizm wobec ",zemsty postmodernizmu”, „Przegląd Prawa i Administracji” 2017, 110, s. 101-102.

66 Pozostawiamy na razie bez rozstrzygnięcia kwestię tego, czy społeczne (the social) może i powinno być odróżniane - na gruncie krytycznej jurysprudencji - od "tego, co prawne” (the juridical). 
w prawie, jak i poprzez próbę zmiany prawa w celu zmiany układu sił (ekonomicznych, społecznych). W tym więc sensie, parafrazując Clausewitza, można powiedzieć, że krytyczna nauka o prawie jest polityką prowadzoną „innymi” (tj. prawniczymi) środkami. Praktycznymi przykładami tak pojmowanej krytycznej nauki prawa jest zjawisko tzw. radykalnej praktyki prawa (radical lawyering), która w swym anglosaskim mateczniku prowadzona jest za pomocą tzw. spraw próbnych (test cases), gdzie radykalni prawnicy celowo doprowadzają do sporu sądowego, aby wymóc zmianę prawa ${ }^{67}$. Oczywiście występowanie takiego zjawiska uwarunkowane jest szeregiem założeń brzegowych dotyczących kultury prawnej, jak choćby możliwość sądowego tworzenia prawa (prawo precedensowe) czy też określona rola społeczna wspólnoty prawniczej, a w szczególności sądów.

Po drugie, nawiązując do tezy o społecznym tworzeniu rzeczywistości, należy podkreślić, że z perspektywy krytycznej nauki prawa prawo jest wytworem spolecznym $^{68}$. Ta presupozycja ontologiczna radykalnie odcina krytyczną naukę prawa od wszelkich nurtów zakładających, że normatywność wynika z ontologii (np. C. Schmitt twierdzący, że prawo jest schronieniem społeczeństwa, a normalność poprzedza normatywność, czy też ujęcia naturalistyczne - klasyczny jusnaturalizm, czy współczesny biologizm i ekonomizm prawniczy). Zbliża natomiast, paradoksalnie, krytyczną naukę o prawie do klasycznych postaci pozytywizmu prawniczego, akcentujących woluntaryzm prawa (prawo jako wyraz woli suwerena, a nie pochodna jakiegokolwiek innego zjawiska, naturalnego bądź kulturowego). Oczywiście, nie znaczy to, by prawo było tworzone w oderwaniu od warunków społecznych; wręcz przeciwnie, dla jurysprudencji krytycznej prawo jest wytwarzane i reprodukowane w określonym kontekście społecznym, w ramach określonej formacji społeczno-gospodarczej, co - wedle dobrze znanych mechanizmów, opisanych już dawno - w ostatecznym rozrachunku determinuje jego treść. Woluntaryzm prawotwórcy (ustawodawcy, sędziego-aktywisty ${ }^{69}$ ) jest zatem ograniczony miejscem w strukturze konfliktów, wskutek czego jego swoboda nie jest aż tak wielka, jak mogłoby się prima facie wydawać. Dla prawoznawstwa krytycznego kluczowy jest jednak moment dialektyczny, a zatem ujęcie prawa w dynamizmie jego relacji ze światem społecznym, a nie jedynie w sposób jednostronny jako jego pochodna (co odróżnia krytyczną naukę o prawie od pewnych uproszczonych

67 Szerzej zob. D. Kennedy, The Hermeneutic of Suspicion in Contemporary American Legal Thought, „Law and Critique" 2015, 25.

68 Por. A. Sulikowski, K. Otręba, op. cit., s. 9: „Prawo jest bowiem przez legal critics traktowane jako wieloaspektowy zespół praktyk społecznych bądź też jako wytwór dyskursów - zorganizowanych wokół pewnych hierarchii i reguł praktyk mówienia, które same wytwarzają swój przedmiot". 
interpretacji marksizmu, wedle których prawo miałoby być jedynie nadbudową, niejako doczepioną do bazy społeczno-ekonomicznej i w całości przez nią zdeterminowaną $)^{70}$.

Po trzecie, nawiązując do tez o interpretacjonalizmie społecznym i wspólnocie interpretacyjnej, należy podkreślić, że zjawisko prawa ma, dla krytycznej nauki o prawie, przede wszystkim charakter wytworu interpretacji ${ }^{71}$. Nie ma bowiem prawa bez interpretacji (nullum ius sine interpretatione), interpretacja zaś jest wytworem wspólnoty interpretacyjnej, która stawia opór interpretatorowi działającemu w określonym kontekście społecznym, zaś uprzywilejowanie określonych interpretacji i nadanie im pierwszeństwa przed innymi jest wpisane w szerszy kontekst polityczności. To założenie, podzielane przez znaczną część współczesnych nurtów filozofii prawa, wyraźnie jednak odróżnia krytyczną naukę o prawie od dogmatyk prawniczych.

\section{Podsumowanie}

Wskazane w dotychczasowych rozważaniach presupozycje ontologiczne krytycznej nauki o prawie determinują - obok jej założeń metodologicznych - szczególny charakter tej nauki, odróżniający ją od pozostałych nauk prawnych. Nie będzie chyba przesadą stwierdzenie, że podstawowy charakter ma dla niej triada polityczności (konflikt-dominacja-emancypacja), a zatem uznawanie tych zjawisk za jak najbardziej realne i relewantne dla prawa. Pozostałe presupozycje mają, jak się wydaje, charakter pomocniczy i pochodny względem założenia o polityczności prawa. Wyraźne sformułowanie fundamentalnych presupozycji ontologicznych krytycznej nauki o prawie pozwala, z jednej strony, dookreślić zakres nurtów badawczych, które mogą zostać do niej zaliczone, a z drugiej strony otwiera możliwość analizy podobieństw i różnic pomiędzy krytyczną nauką o prawie a rozmaitymi innymi nurtami obecnymi we współczesnym prawoznawstwie. $Z$ racji podejścia krytycznej nauki o prawie do problematyki dyscyplinarności, a w szczególności głoszonej przez nią postdyscyplinarności względnie integracji nauk, konceptualizacja presupozycji ontologicznych pozwoli też na bardziej owocny dialog z przedstawicielami innych nauk nieprawnych, a w szczególności filozofii ogólnej, filozofii polityki, socjologii czy teorii kultury.

70 Por. R. Mańko, W stronę..., s. 62-66.

71 Por. A. Sulikowski, K. Otręba, op. cit., s. 9-10. 


\section{Bibliografia}

Berger P.L., Luckmann T., Społeczne tworzenie rzeczywistości, Warszawa 1983.

Dębska H., Law's Symbolic Power: Beyond The Marxist Conception of Ideology, "Wrocław Review of Law, Administration and Economics" 2015, 5(1), s. 5-6.

Dębska H., Władza, symbol, prawo. Społeczne tworzenie Trybunału Konstytucyjnego, Warszawa 2015.

Dębska H., Prawo jako pole (ujęcie modelowe), „Państwo i Prawo” 2016, 71(9), s. 36-53.

Dębska H., Warczok T., The Social Construction of Femininity in the Discourse of the Polish Constitutional Court, [w:] R. Mańko et al. (red.), Law and Critique in Central Europe: Questioning the Past, Resisting the Present, Oxford 2016, s. 106-130.

Douzinas C. et al. (red.), Politics, Postmodernity and Critical Legal Studies. The Legality of the Contingent, London-New York 1994.

Douzinas C., Gearey A., Critical Jurisprudence. The Political Philosophy of Justice, Oxford-Portland 2005.

Douzinas C., Warringron R., McVeigh S., Postmodern Jurisprudence. The Law of Text in the Texts of Law, London-New York 1991.

Drong L., Od konwencjonalizmu do normatywizmu. Kilka uwag o ewolucji poglądów teoretycznoliterackich Stanleya Fisha, „ER(R)GO. Teoria. Literatura. Kultura” 2016, 12(1), s. 27-36.

Epstein B., A Framework for Social Ontology, "Philosophy of the Social Sciences” 2016, 46(2), s. 147-167.

Feyerabend P., Przeciw metodzie, Wrocław 1996.

Fish S., Working on the Chain Gang: Interpretation in the Law and in Literary Criticism, "Critical Inquiry" 1982, 9(1), s. 201-216.

Fish S., Interpretacja, retoryka, polityka, Warszawa 2008.

Kaczmarek P., Jabłoński P., Granice władzy prawniczej w perspektywie polskiej tradycji socjologicznej, Kraków 2017.

Kennedy D., The Hermeneutic of Suspicion in Contemporary American Legal Thought, "Law and Critique" 2015, 25(2), s. 91-139.

Kojève A., Outline of a Phenomenology of Right, Lanham 2000.

Kozak A., Granice prawniczej władzy dyskrecjonalnej, Wrocław 2002.

Kozak A., Myślenie analityczne w nauce prawa i praktyce prawniczej, Wrocław 2012.

Lang W., Wróblewski J., Zawadzki S., Teoria prawa, Warszawa 1986.

Leiter B., The Hermeneutics of Suspicion: Recovering Marx, Nietsche and Freud, The University of Texas School of Law. Public Law and Legal Theory Working Paper 72, 2005, http://ssrn.com/abstract=691002 (dostęp: 2.02.2018)

Leszczyński J., Pozytywizacja prawa w dyskursie dogmatycznym, Kraków 2010.

Łakomy J., Interdyscyplinarność i integracja zewnętrzna nauk prawnych w świetle postmodernistycznej krytyki, „Archiwum Filozofii Prawa i Filozofii Społecznej” 2011, 2(1), s. 29-45.

Łakomy J., Spory wokót wykładni prawa między nowoczesnością a ponowoczesnością. Na przykładzie debaty Dworkina z Fishem, [w:] A. Samonek (red.), Teoria prawa między nowoczesnością a ponowoczesnością, Kraków 2012, s. 213-221. 
Łakomy J., 2017, The Space of the Political in Legal Interpretation (Some Remarks on the Dworkin-Fish Debate), [w:] P. Bieś-Srokosz et al. (red.), Law, Space and the Political: An East/West Perspective, Częstochowa (w druku).

Mańko R., 2014, Koncepcja interpelacji ideologicznej a krytyczny dyskurs o prawie, „Archiwum Filozofii Prawa i Filozofii Społecznej" 8(1), s. 41-54.

Mańko R., 2016, Ideology and Legal Interpretation: Some Theoretical Considerations, [w:] K. Torgāns et al. (red.), Constitutional Values in Contemporary Legal Space, t. 1, Riga, s. 117-126.

Mańko R., 2017, Symbolic Violence in Technocratic Law and Attempts at Its Overcoming: Politicisation through Humanization?, „Wrocławskie Studia Erazmiańskie” 11, s. 31-64.

Mańko R., W stronę krytycznej filozofii orzekania. Polityczność, etyka, legitymizacja, Łódź 2018.

Minda G., Postmodern Legal Movements. Law and Jurisprudence at Century's End, New York 1995.

Mouffe C., Polityczność, Kraków 2015.

Mouffe C., Laclau E., Hegemonia i socjalistyczna strategia. Przyczynek do projektu radykalnej polityki demokratycznej, Wrocław 2005.

Nagel T., Widok znikąd, Warszawa 1997.

Nyström P., Disciplinarity, Inter-disciplinarity and Post-disciplinarity: Changing Disciplinary Patterns in the History Discipline, [w:] La interdisciplinaridad y la transdisciplinaridad en la organización de conocimiento científico, León 2007, s. 123-132.

Opałek K., Problemy metodologiczne nauki prawa, Warszawa 1962.

Opałek K., Wróblewski J., Prawo. Metodologia, filozofia, teoria prawa, Warszawa 1991.

Paździora M., Stambulski M., Co może dać nauce prawa polityczność? Przyczynek do przyszłych badań, „Archiwum Filozofii Prawa i Filozofii Społecznej” 2014, 8(1), s. 55-66.

Pietrzykowski T., 2017, Naturalizm i granice nauk prawnych. Esej z metodologii prawoznawstwa, Warszawa.

Schmitt C., Pojęcie polityczności, [w:] idem, Teologia polityczna i inne pisma, Warszawa 2012, s. 245-314.

Shusterman R., Estetyka pragmatyczna. Żywe piękno i refleksja nad sztuka, Wrocław 1998. Skuczyński P., Typy myśli krytycznej w prawoznawstwie. Od krytyki poznania do walki o uznanie, [w:] T. Bekrycht et al. (red.), Integracja zewnętrzna i wewnętrzna nauk prawnych, t. 1, Łódź 2014, s. 133-148.

Smolak M., Presupozycje ontologiczne tekstu prawnego, „Ruch Prawniczy, Ekonomiczny i Socjologiczny" 2011, 73(4), s. 41-51.

Stambulski M., Polityczność jako etyka polityczna prawa, [w:] M. Dudek et al. (red.), Aksjologiczny wymiar prawa, Kraków 2015.

Stambulski M., The Critique of Ideological Legal Reason, „Wrocław Review of Law, Administration and Economics" 2015, 5(1), s. 48-60.

Stone M. (red.), New Critical Legal Thinking. Law and the Political, Abingdon 2014.

Sulikowski A., Afirmatywna amnezja i konserwatywni 'crits'. Kilka uwag o kondycji krytycznej myśli prawniczej w Europie Środkowej i Wschodniej, "Archiwum Filozofii Prawa i Filozofii Społecznej" 2014, 8(1), s. 77-87. 
Sulikowski A., Idee i metody wspótczesnych krytycznych studiów nad prawem, „Przegląd Prawa Publicznego" 2015, 7-8, s. 9-21.

Sulikowski A., Prawa a ideologia. Prawa jednostki z perspektywy krytycznej myśli prawniczej i społecznej (wybrane zagadnienia), „, Roczniki Nauk Społecznych” 2015, 7(43), s. 17-32.

Sulikowski A., Trybunał Konstytucyjny a polityczność. O konsekwencjach upadku pewnego mitu, „Państwo i Prawo” 2016, 71(4), s. 3-14.

Sulikowski A., Konstytucjonalizm wobec "zemsty postmodernizmu”, „Przegląd Prawa i Administracji" 2017, 110, s. 95-106.

Sulikowski A., Otręba, K., O potrzebie studiów krytycznych nad prawem konstytucyjnym, „Państwo i Prawo" 2017, 72(3), s. 5-16.

Škop M., The Importance of Being a Linguist: Critical Legal Thought in Central Europe, [w:] R. Mańko et al. (red.), Law and Critique in Central Europe: Questioning the Past, Resisting the Present, Oxford 2016, s. 32-43.

Šulmane D., Ideology, Nationalism and Law: Legal Tools For An Ideological Machinery in Latvia, „Wrocław Review of Law, Administration and Economics" 2015, 5(1), s. 61-78.

Ward I., An Introduction to Critical Legal Theory, London-Sydney 1998.

Zirk-Sadowski M., Prawo a uczestniczenie w kulturze, Łódź 1998.

Zomerski W., Ideology In Modern Times: Three Ideological Lies Behind Universal Human Rights, „Wrocław Review of Law, Administration and Economics" 2015, 5(1), s. 119-127.

Zomerski W., Krytyczna analiza dyskursu sądowego dotyczacego prawnej sytuacji osób homoseksualnych w świetle art. 18 Konstytucji RP, "Archiwum Filozofii Prawa i Filozofii Społecznej" 2017, 15(2), s. 80-97.

Žižek S., The Sublime Object of Ideology, London 2008. 